\title{
Effect of Process Condition on the Bio-Digestion of Cow Dung for Organic Fertilizer Production
}

\author{
Udeh Sunday ${ }^{1}$, Ekumankama Ekuma Onu² \\ ${ }^{1}$ Department of Chemical Engineering, Institute of Management \& Technology, Enugu, Nigeria \\ ${ }^{2}$ Department of Food Science \& Technology, Ebonyi State University, Abakaliki, Nigeria
}

\section{Email address:}

udehsunday1958@gmail.com (U. Sunday)

\section{To cite this article:}

Udeh Sunday, Ekumankama Ekuma Onu. Effect of Process Condition on the Bio-Digestion of Cow Dung for Organic Fertilizer Production. American Journal of Chemical Engineering. Vol. 6, No. 5, 2018, pp. 99-106. doi: 10.11648/j.ajche.20180605.14

Received: September 18, 2018; Accepted: September 30, 2018; Published: November 1, 2018

\begin{abstract}
Studies were conducted on the biodigestion of cow-dung into organic fertilizer with the aim of determining the effect of process parameters on the quality of the product. The Hydrogen ion index $(\mathrm{pH})$ was varied from 3.5 to 7.0 whereas the microbe: substrate $(\mathrm{M} / \mathrm{S})$ ratio was varied from 1.33 to $4.5 \mathrm{~g} / \mathrm{kg}$ and biodigestion time from 3 to $24 \mathrm{hrs}$. The fertilizer produced was characterized by the NPK content and the production index (PI). The extent of biodigestion as indicated by the PI value, varied with the $\mathrm{pH}$, ranging from 0.068 to 0.109 for $\mathrm{pH}$ between 3.5 to 7.0. Hydrogen ion index (pH) range of 3.5-4.0 at the temperature of $350^{\circ} \mathrm{C}$, using native microbial flora were discovered to be most favorable to the biodigestion process, with PI 0.109 to 0.12 . It was also discovered that the use of mixed culture (native microbe plus cultured saccharomyces cerevisiea further enhanced the result. A maximum microbe-substrate ratio of $4.5 \mathrm{~g} / \mathrm{kg}$ and a minimum of $2.67 \mathrm{~g} / \mathrm{kg}$ on mass basis were recommended. Within a bioconversion period of nine hours (9hrs), a product with N. P. K values of 2.9; 0.016, and 1.55 was obtained representing an increase in fertilizer value by $61.1 \%$ and $78.5 \%$ in Nitrogen $(\mathrm{N})$ and potassium nutrient compositions respectively within the period. The fertilizer has an acceptable odour when dried and readily available to plant on application. It was also observed that the biodigestion process generated an exceeding quantity of biogas which can be trapped and upgraded for other domestic and industrial applications.
\end{abstract}

Keywords: Biodigestion, Fertilizer, Sustainability, Ozone

\section{Introduction}

Before the age of modern technology, demands for greater agricultural yields in Nigeria and many other nations in the world were met by shifting cultivation, irrigation and clearing of forested areas.

During the primitive era in Africa, and until about the year 1900 in United States of America, the demands for high agricultural yields were met by bringing new lands into cultivation [23]. The annual loss of lands tourbanization and city expansion, roads and recreational areas will continue in particular in developing nations like Nigeria. It is therefore certain that any substantial improvement in agricultural production must come from larger yields on Lands already in cultivation, and strict regulation on urbanization. This can be achieved through the use of adequate fertilizer. Apart from the conventional inorganic fertilizer, agricultural waste and bye products can be used as fertilizers.

Shifting cultivation was the means of soil nutrient conservation $[3,8,9,26]$. FAO reported on changing trends in shifting cultivation in Africa [11].

The observed increase in plant-nutrient consumption in the recent time indicates that the importance of fertilizer to crop production is widely accepted, both in Africa and other agrarian nations

Fertilizer can be said to be any substance that is added to the soil to supply those elements required by the plant for its growth and overall yield. A complete fertilizer therefore contains the major plant-nutrients elements which includes; nitrogen, phosphorous and potassium-NPK [4]. Basically commercial fertilizer should containdefinite percentages of primary fertilizer elements expressed as Nitrogen (N), Phosphoric acid $\left(\mathrm{P}_{2} \mathrm{Q}_{3}\right)$ and Potach $\left(\mathrm{K}_{2} \mathrm{O}\right)$ and the sum of these components seldom exceed $30 \%$. The portions that remain constitute $70-85 \%$ by weight of most fertilizers [18]. 
Furthermore, recognition of increasing severity of solid wastes problem has resulted in an increased research effort to find uses for waste materials which might assist in conserving our resource and decrease disposal costs.

Food and Agricultural Organization of the United Nations (FAO) in conjunction with the UnitedNations Environmental Protection Agency (UNEP) convened a seminar on "Residue utilization, management of agricultural and agro-industrial wastes" in Rome from 18-21 Jan. 1979. The results of the seminar indicated the necessity of compiling on a continuing basis and disseminating information on the economic utilization of residues in agriculture, fisheries and related industries [10]. Biodigestion had been identified as a very successful way of utilizing these agric wastes.

High interest in anaerobic digestion was sparked by the energy crisis in the 1970s [17]. Klinkner further reported that anaerobic digesters are now commonly found alongside farms to reduce nitrogen run-off from manure or waste water treatment facilities to reduce sludge disposal cost [17].

Many scholars have worked on the extraction of methane from cow dung, plants bye products, poultry droppings, goat and sheep dung and waste water. From their studies, it was found that the entire slurry/sludge of the agriculture byeproducts/waste from the anaerobic digestion is an excellent source of organic fertilizer with obvious advantages over the mineral/chemical fertilizers $[1,2,7,13,15,25,27,31]$. The advantage of the organic fertilizer was also reported by an eminent scholar who stated that the organic fertilizer, while they feed the plant, they also build the soil; they are also more environmentally friendly [19].

Argument against inorganic fertilizer includes the fact that:

i. Artificial (inorganic) fertilizers -NPK are serious pollutants especially of waterways.

ii. Phosphates used in constituting them are very expensive and usually scarce.

iii. Artificial fertilizers lead to soil erosion and impoverishments and can cause irreversible damage to soil $[7,14]$.

In the light of the above shortcomings and problems arising from continuous application of artificial (inorganic) fertilizer; the need to research and perhaps improve on the traditional method of soil nutrient enrichment (the use of manure, crop residues, animal droppings and even sewage) became obvious.

The advantages of preserving and recycling the nutrients within the agro ecosystem; improving soil fertility, reducing the need for inorganic fertilizer and hence preventing pollution, surely justify the efforts being made towards commercial production of organic fertilizers. Furthermore, the fact that cow dung which is abundant in Nigeria and many developing countries in the world is underutilized, has also motivated this study.

Objectives and Scope

The main objective of this work was to determine the effect of process parameters on the production of organic fertilizerthrough biodigestion ofcow dung.

The optimum hydrogenionindex $(\mathrm{pH})$ and microbe dosagewere determined on the basis of the process parameter that maximized the production index (PI) which is the measure of extent of biodegration/biodigestion of the cow dung.

\section{Experimental}

Materials from a typical small scale cattle ranch in Awkunanaw Enugu, Nigeria was used, and Brewers' yeastsacharomycescerevisiae.

One hundred and fifty grams (150gm) of the 'cow dung' was measured into five conical flasks and each mixed with $300 \mathrm{mls}$ of water and well dispersed with a mixer. The $\mathrm{pH}$ values of the four samples were adjusted to $\mathrm{pH} 7,5,4.5,4.0$ and 3.5 respectively. The initial viscosities of the samples were read with a HAAKA Viscotester-VT-01 at $30^{\circ} \mathrm{C}$ and allowed to stand at this temperature in a temperature controlled water bath. The production indices were read at time intervals of $3,6,9,12$, 15and 24hours.

The method described above was repeated at the constant temperature of $35^{\circ} \mathrm{C}$ with additions of $0.2 \mathrm{gm}, 0.4 \mathrm{gm}$ and $0.6 \mathrm{gm}$ of saccharomyces cerevisiae to each sample. The production index, viscosity and density were evaluated at the selected time intervals.

The basic element of interest ( $\mathrm{N}, \mathrm{P}$ and $\mathrm{K}$ ) were analyzed using titration, wet-ash method and corning 400 Model flame photometer, while the viscosities were determine using the HAAK Viscometer Vt-01. The production index (PI) defined as the ratio of change in kinematic viscosity at a given temperature, $\Delta v$ divided by the initial kinematic viscosity, $v i$, at the same temperature was evaluated as follows:

$$
\mathrm{PI}=\frac{\Delta \text { ? }}{\text { ? } \mathrm{i}}
$$

\section{Results and Discussion}

The progress of the biodigestion was monitoredby the variation of viscosity with time at the temperature of $30^{\circ} \mathrm{Cand}$ variouspH as shown in Figure 1 .

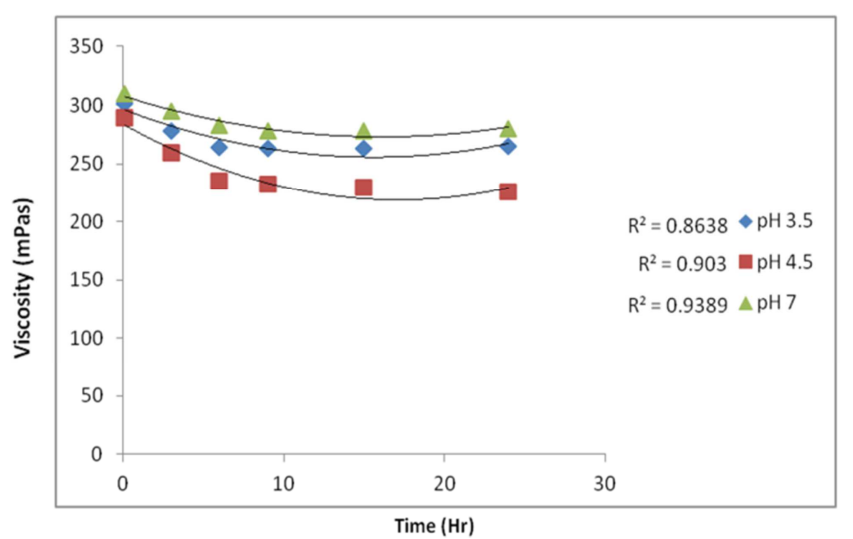

Figure 1. Variation of Visosity of cow dung slurry with time during biodigestion with native microbes at some selected $\mathrm{pH}$.

Results presented in this Figure show that viscosity of the 
cow dung solution digested at $30^{\circ} \mathrm{C}$ generally decreased with time. Biodigestion at a $\mathrm{pH}$ of 3.5 for instance resulted in viscosity variation form $302 \mathrm{mPas}$ to $273 \mathrm{mPas}$ for digestion time of $0-24 \mathrm{hrs}$. The results further show that there was not significant change in viscosity after digestion time of 9 hours. This figure presented results obtained at $\mathrm{pH}$ of $3.5,4.5$ and 7.0. Results obtained at $\mathrm{pH}$ of 4.0 and 5.0 did not significantly vary from those obtained at $\mathrm{pH}$ of 4.5 and hence clustered when plotted. Consequently Table 1 is presented to show the differences in the $\mathrm{pH}$ range of 4.0 to 5.0.

Table 1. Variation of Viscosity with $\mathrm{pH}$ and Time during Biodigestion with Native Microbes at $30^{\circ} \mathrm{C}$.

\begin{tabular}{lllllll}
\hline \multicolumn{7}{c}{ viscosity (M. Pa. s) at $\mathbf{3 0} \mathbf{C}^{\circ} \mathbf{C}$} \\
\hline $\mathbf{p H}$ & $\mathbf{0 . 0 h}$ & $\mathbf{3 . 0 H r}$ & $\mathbf{6 . 0 H r}$ & $\mathbf{9 . 0 H r}$ & $\mathbf{1 5 H r}$ & $\mathbf{2 4 H r}$ \\
\hline 3.5 & 302 & 278 & 264 & 263 & 263 & 265 \\
4.0 & 293 & 263 & 245 & 238 & 239 & 239 \\
4.5 & 290 & 260 & 235 & 233 & 230 & 226 \\
5.0 & 291 & 262 & 240 & 235 & 236 & 237 \\
7.0 & 310 & 295 & 283 & 278 & 278 & 280 \\
\hline
\end{tabular}

Digestion process being a biodegradation process, results in the conversion of higher molecular components such as the proteins and carbohydrates to lower molecular weight components. The higher molecular weight components resulted in solutions with higher viscosity than solutions of lower molecular weight substances. This is responsible for the observed decrease in viscosity with digestion time.

These results also show that the viscosity was lowest in the $\mathrm{pH}$ range of 4.5 and 5.0 and as digestion $\mathrm{pH}$ increases, the viscosity of the cow-dung solution decreases. The carbon to Nitrogen ratio $(\mathrm{C}: \mathrm{N})$ of cow dung is low 7.9. Agricultural scholarsreported that low $\mathrm{C}: \mathrm{N}$ ratio in cow dung manure is an indication that it could be a good source of protein for the microbes involved in organic matters decomposition [13, 14]. This low $\mathrm{C}: \mathrm{N}$ ratio is an indication of low mineralization [24]. Considering these of reports, it can be seen that cow dung is highly organic and protein content is high. Protein solutions become more gel-like as acidity increases that is as $\mathrm{pH}$ decreases and the proteins precipitates at their isoelectric point. Conversely as $\mathrm{pH}$ increases or alkalinity increases, the protein solutions get more molten resulting in lower viscosity. This is responsible for the observed decrease in viscosity with increase in $\mathrm{pH}$ during digestion of the cow dung.

Figure 2, shows how the addition of the Yeast, saccharomyces cerevisiae influenced the activities of the Native Microbial Flora.

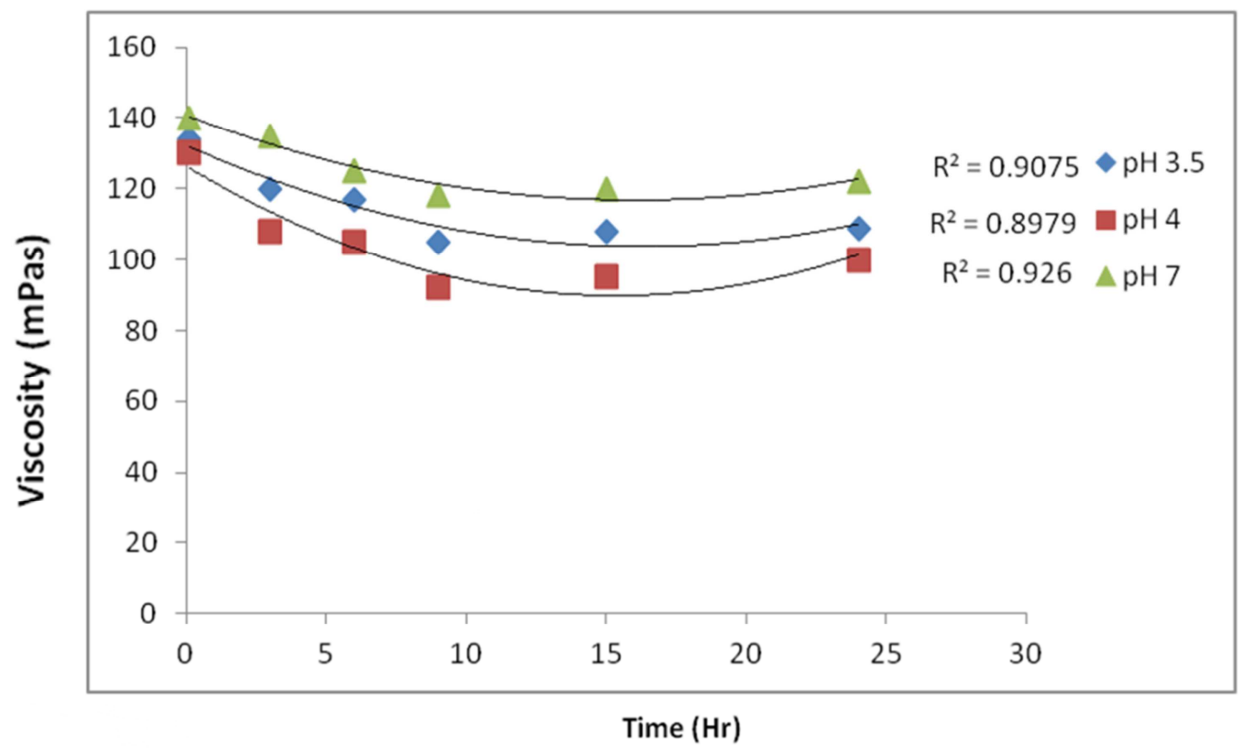

Figure 2. Variation of viscosity of cow dung slury with time during biodigestion with mixed culture at some selected pH.

From this result (Figure 2), it can be seen that a trend similar to that obtained without addition of yeast saccharomyces cerevisieawas obtained. In other words the viscosity of the product generally decreased with increase inbiodigestion time and had the lowest values in the $\mathrm{pH}$ range of 4.0 to 5.0 as further buttressed in Table 2 .

Comparing values in Figures 1 and 2, it can be seen that the viscosity of the products were lower in the case of mixed culture where yeast was added to the cow dung in addition to the native microbes. This observation could be due to the fact that the yeast may have enhanced the degradation of some carbohydrates in cow dung. This is substantiated by the work of some other researchers who reported that some yeast areknown to be effective in the degradation of starch and carbohydrates [14, 16, 20, 27].

Table 2. Variation of Viscosity with Time during Bio Conversion with MixedCulture at $30^{\circ} \mathrm{C}$ and the $\mathrm{pH}$

\begin{tabular}{lllllll}
\hline \multicolumn{7}{c}{ viscosity (M. Pa. s) } \\
\hline $\mathbf{p H}$ & $\mathbf{0 . 0 H r}$ & $\mathbf{3 . 0 H r}$ & $\mathbf{6 . 0 H r}$ & $\mathbf{9 . 0 H r}$ & $\mathbf{1 5 H r}$ & $\mathbf{2 4 H r}$ \\
\hline 3.5 & 134 & 120 & 117 & 105 & 108 & 109 \\
4 & 130 & 108 & 105 & 92 & 95 & 100 \\
4.5 & 133 & 119 & 116 & 95 & 100 & 104 \\
5 & 135 & 121 & 118 & 100 & 105 & 109 \\
7 & 140 & 135 & 125 & 118 & 120 & 122 \\
\hline
\end{tabular}




\subsection{Production Index (Pi)}

How the PI varied with biodigestion time and $\mathrm{pH}$ using native organisms is presented in Figure 3. The result showed a rapid rise in PI in the first three hours, followed by gradual increase in the value with time, up to $9 \mathrm{hr}$ and slight decrease in PI afterwards.

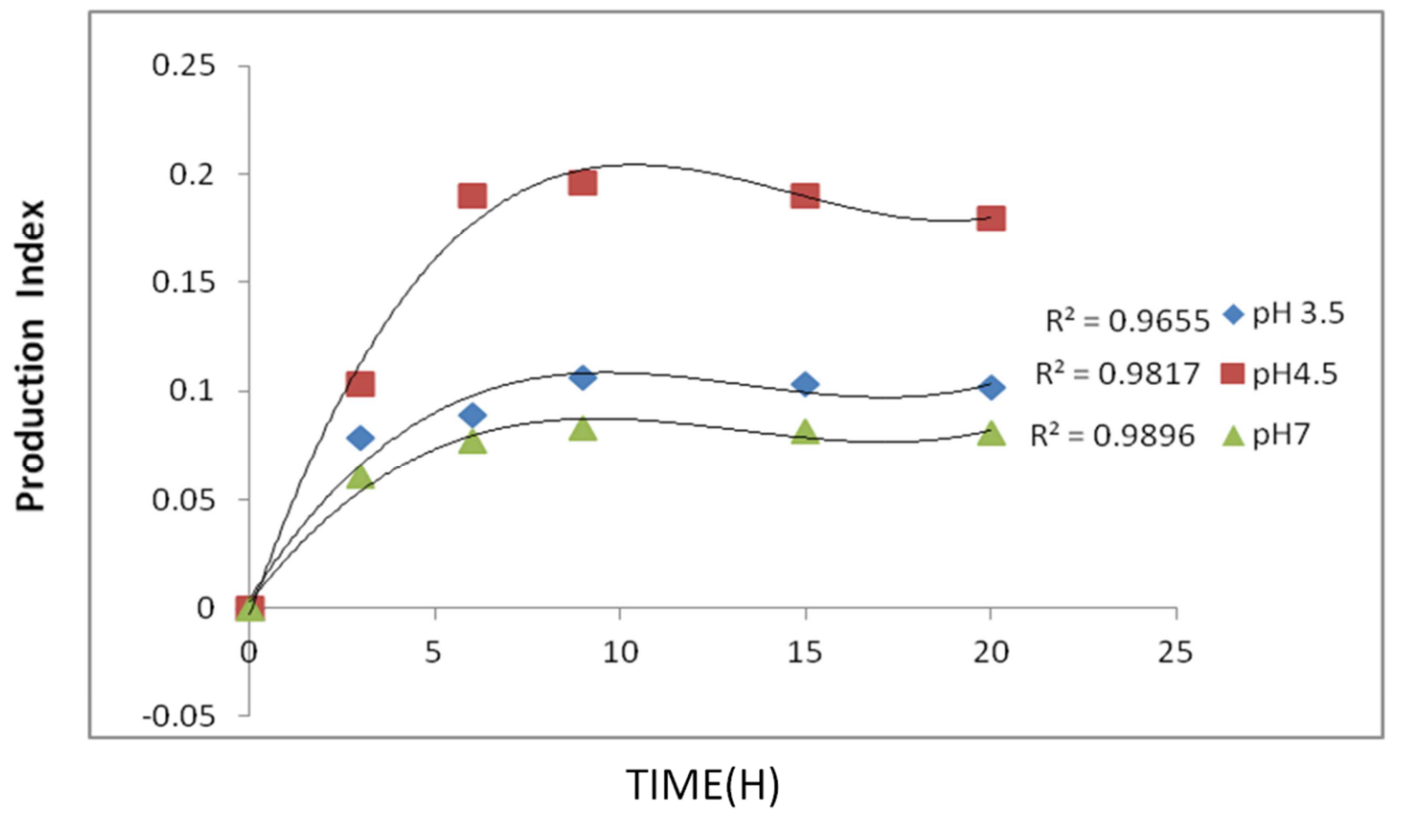

Figure 3. VariationofProductionIndex(PI)withTimeduringBiodigestion with Native Microbes at selected pH.

The observation in the digestion period up to 9 hours indicated that the effect of rapid breakdown of the biodegradable components into smaller molecules dominated the process. After 9 hours, evaporation of moisture, volatile components and biogas which cause thickening of the product starts dominating, resulting in the observed increase in viscosity and consequent decrease in the PI.

Similar trend was obtained using a mixed culture of native organisms and yeast-saccharomyces cerevisieaas shown in Figure 4.

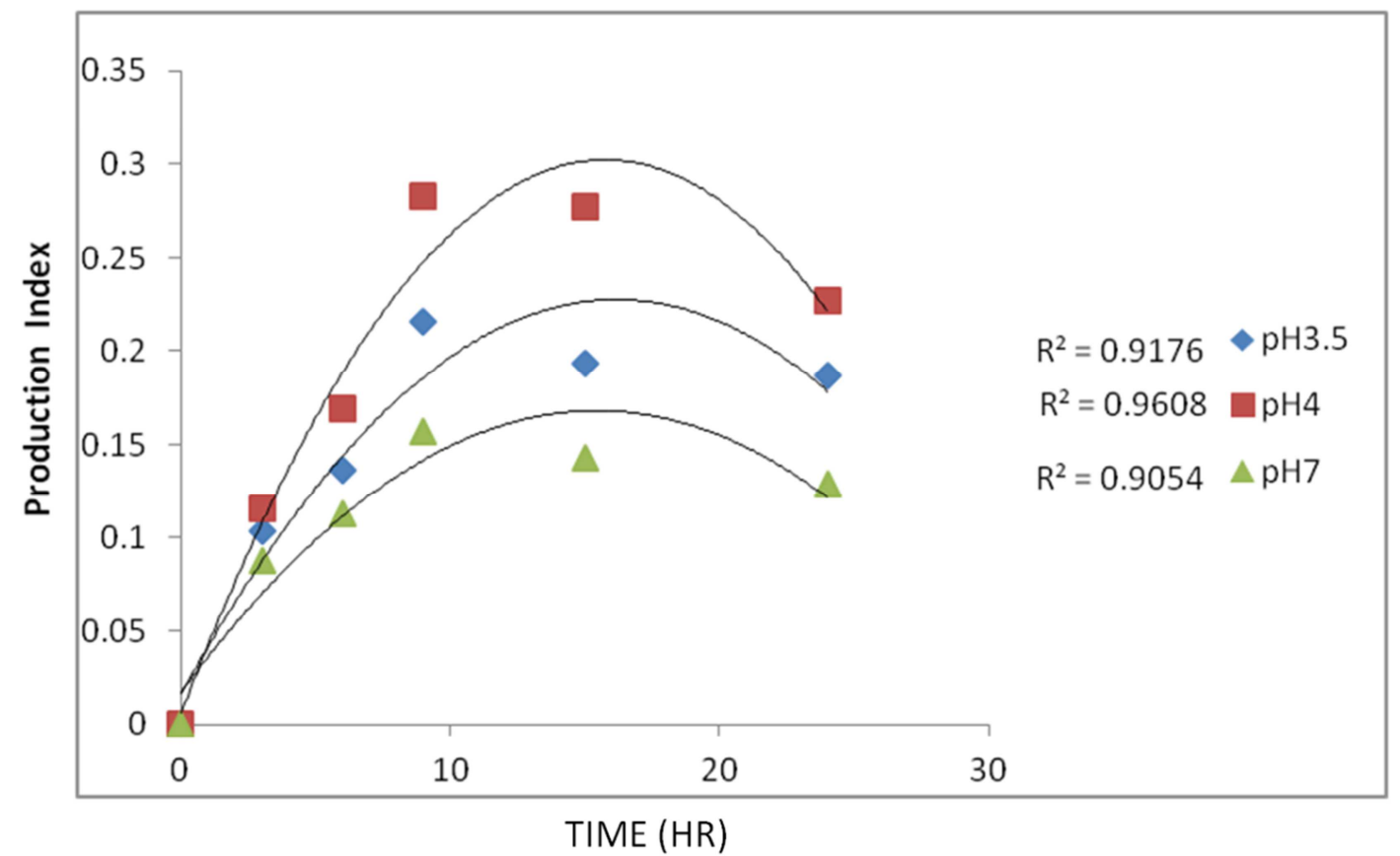

Figure 4. Variation of production index (PI) with time during biodigestion with mixed culture at some selected PH.

Comparing this result with that of native culture (Figure 3) it can be seen that PI with mixed culture was higher probably due to the fact that rate of biodegradation was higher in the presence of mixed culture, since saccharomyces cerevisiea could degrade some components that the native microbes could not degrade or may be slow at degrading. 
From the result presented in Figures 3 and 4, it can be seen that there was a steady increase in production index in the first eight to nine hours in all the process conditions of $\mathrm{pH}$ considered, followed by a steady decline after nine hours. This was expected, because the first eight hours witnessed increase in microbe concentration due to growth hence increase in their activities then followed by a stationary growth, phase between 8 and 9 hours and lastly, period of decline probable due to death of some organisms, evaporation, side and reactions. Table 3 shows this observation for all the digestion $\mathrm{pH}$ considered.

Table 3. Variation of Production Index with Time and $p H$ using Mixed Culture.

\begin{tabular}{llllll}
\hline \multirow{2}{*}{$\mathbf{p H}$} & \multicolumn{6}{l}{ Production Index at Various Digestion Time } \\
\cline { 2 - 6 } & $\mathbf{3 ~ H r}$ & $\mathbf{6 ~ H r}$ & $\mathbf{9 ~ H r}$ & $\mathbf{1 5} \mathbf{~ H r}$ & $\mathbf{2 4} \mathbf{~ H r}$ \\
\hline 3.5 & 0.104 & 0.137 & 0.216 & 0.194 & 0.187 \\
4.0 & 0.116 & 0.169 & 0.283 & 0.278 & 0.227 \\
4.5 & 0.114 & 0.168 & 0.270 & 0.274 & 0.218 \\
5.0 & 0.104 & 0.143 & 0.229 & 0.222 & 0.193 \\
7.0 & 0.088 & 0.113 & 0.121 & 0.143 & 0.129 \\
\hline
\end{tabular}

\subsection{Elemental Composition}

The raw material (cow dung) used and the products of the bioconversion were analyzed for the basic elements of interest, nitrogen, phosphorous and potassium contents. The results obtained are presented in Table 4.

Table 4. Fertilizer Value (N: P: K) of Raw and biodigested Cow dung.

\begin{tabular}{llll}
\hline SAMPLE & NITRO. N & PHOSPHO. P & POTAS. K \\
\hline Raw cow dung & 1.800 & 0.18 & 0.840 \\
Native Microb, pH 4 & 2.040 & 0.20 & 1.510 \\
Mixed culture pH4.5 & 2.900 & 0.20 & 1.510 \\
Mixed culture, pH5 & 1.980 & 0.20 & 1.140 \\
MEAN & 2.18 & 0.20 & 1.50 \\
\hline
\end{tabular}

From this result it can be seen that raw cow dung used in this work has a Nitrogen $(\mathrm{N})$ content of $1.8 \%$, phosphorus $(\mathrm{P})$ content of $0.18 \%$ and Potasium $(\mathrm{K})$ content of $0.84 \%$. This correspond to NPK value of 1.8-0.18-0.84. An eminent scholar reported a Nitrogen content of 1.6\%, Phosphorus content of $0.7 \%$ and potassium content of $0.53 \%$ corresponding to NPK value of 1.6-0.76-0.53 for cow dung, [24] and other scholars reported that cow dung has Nitrogen, phosphorus and potassium contents of $3 \%, 2 \%$ and $1 \%$ respectively, which is equivalent to fertilizer NPK rating, of 3-2-1, while another reported an N-P-K rating of 2-2-2 for cow dung fertilizer called "Fertiplus cow" $[19,30]$.

Comparing the results of this work with those of other scholars, it can be seen that there is a variation of NPK value used in this work with those in the literature [24, 30]. The major reason could be associated with the variation in the diet consumed by the cows, the age and the specie of the cow.

The elemental composition of the cow dung after biodigestion indicated increase in the nitrogen, potassium and phosphorous content. Digestion using mixed culture containing native microbes and yeast saccharomyces cerevisiea had the highest nitrogen $(\mathrm{N})$ content of $2.9 \%$ followed by digestion with the native microbes only with Nitrogen content of $2.04 \%$. the potassium content obtained was $1.5 \%$ for biodigested cow dung irrespective of Whether it was carried out with native microbes or mixed culture containing saccharomyces cerevisiea. However, this potassium content is an improvement on the raw cow dung which had a potassium content of $0.84 \%$. Considering the phosphorous content, its value only slightly increased from $0.18 \%$ in the raw cow dung to $0.20 \%$ in digested cow dung.

This observation suggests that the process of digestion results in the liberation of morelowermolecular weight (more available) nitrogen compounds during the degradation of higher molecular weight (less available) nitrogen compounds. The same is applicable to the potassium and to a lesser extend phosphorous.

The overall implication of this result is that application of digestion process on cow dung enhances its fertilizer potentials and subsequent soil fertility enhancement.

Comparing digestion at $\mathrm{pH}$, results in Table4 show that using the mixed culture, the nitrogen and potassium of product from digestion at $\mathrm{pH} 4$ were higher than those digested at $\mathrm{pH} 5$. This suggest that $\mathrm{pH}$ of 4 is more favourable for the activities of the microbes. This is consistent with the higher production indices obtained at $\mathrm{pH}$ of 4 .

\subsection{Effect of $\mathrm{pH}$ on Biodigestion}

The effect of $\mathrm{pH}$ and digestion time on production index (PI) is presented in figures 5 and6. From the results, it can be seen that the PI is in the order $\mathrm{pH} 4.5>\mathrm{pH} 4.0>\mathrm{pH} 5>\mathrm{pH} 3.5>\mathrm{pH} 7$, when native microbial flora was used (Figure 5). Using the mixed culture of the native flora plus $s$. cerevisias, the result slightly modified to pH4.0 > pH4.5 > pH5 > pH3.5 > pH7 (Figur6).

Yeast can grow in a $\mathrm{pH}$ range of 4 to 4.5 and moulds can grow from $\mathrm{pH} 2$ to 8.5 but favoured at an acid $\mathrm{pH}$, [21].

These results suggest that digestion of cow dung with native microbial flora was most favored at the $\mathrm{pH}$ of 4.5 followed closely by $\mathrm{pH}$ of 4.0 (Figure 5), while digestion with mixed culture was most favoured at the $\mathrm{pH}$ of 4.0 followed by $\mathrm{pH}$ of 4.5 (Figure 6). Therefore the optimum $\mathrm{pH}$ range for this bioconversion is $\mathrm{pH}$ 4.0-4.5.

It was noted that the $\mathrm{pH}$ of the medium increased with time, this, probably, may be attributed to the increase in the nitrogen value of the sample with time in form of ammonia in solution. This also may have been responsible for the observed decrease in PI after the peak value which occurred in the neighbourhood of digestion time of $9 \mathrm{hr}$. 


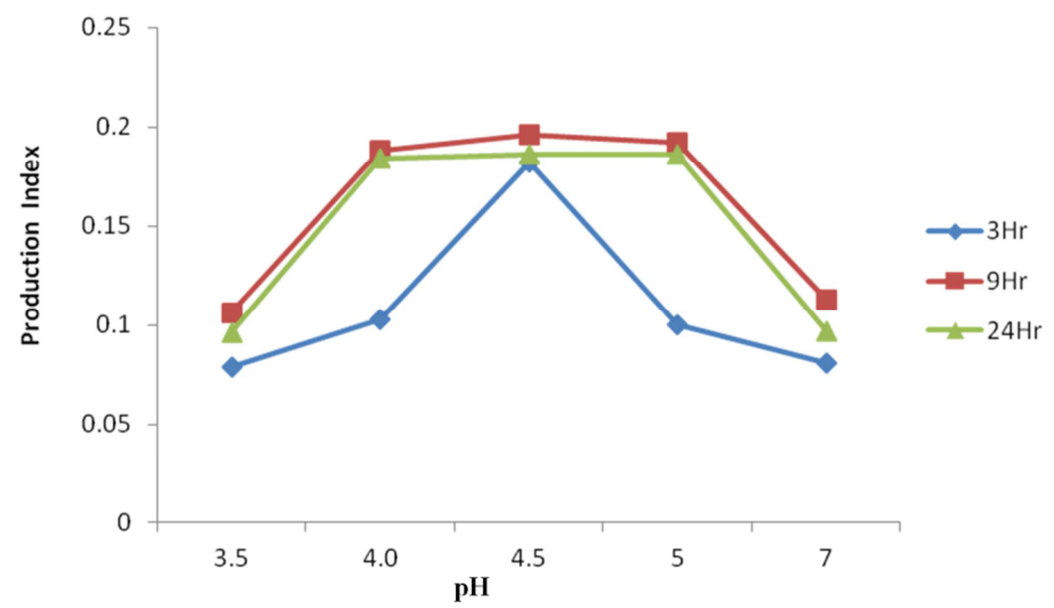

Figure 5. Variation of production index (PI) with pH for cow dungdigested for a specified time using native microbes.

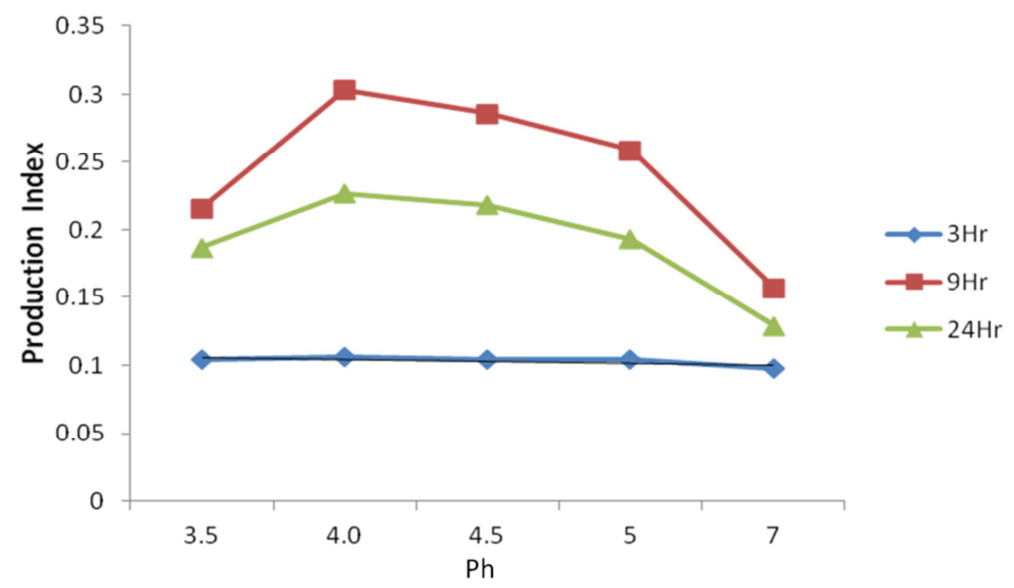

Figure 6. Variation of production Index (PI) with $\mathrm{pH}$ for cow dung digested with mixed culture for a specified time.

\subsection{Effect of Microbe Dosage on the Biodigestion of Cow Dung}

Figure7and Table 5 present the effect of microbe (saccharomyces cerevisiea) dosage on the production index which is the measure of extent of bioconversion.

From figure 7 , it can be seen that using $\mathrm{pH}$ of 4.0 for instance, the PI did not significantly vary with microbe concentration for biodigestion time up to $6 \mathrm{hr}$ after which it increased with increase in concentration of $s$. cerevisiae. Table 5 reveals that maximum result in the production index, was obtained when $4.5 \mathrm{~g} / \mathrm{kg}$ of microbes was used at a digestion $\mathrm{pH}$ of 4.0 and time $9 \mathrm{hr}$

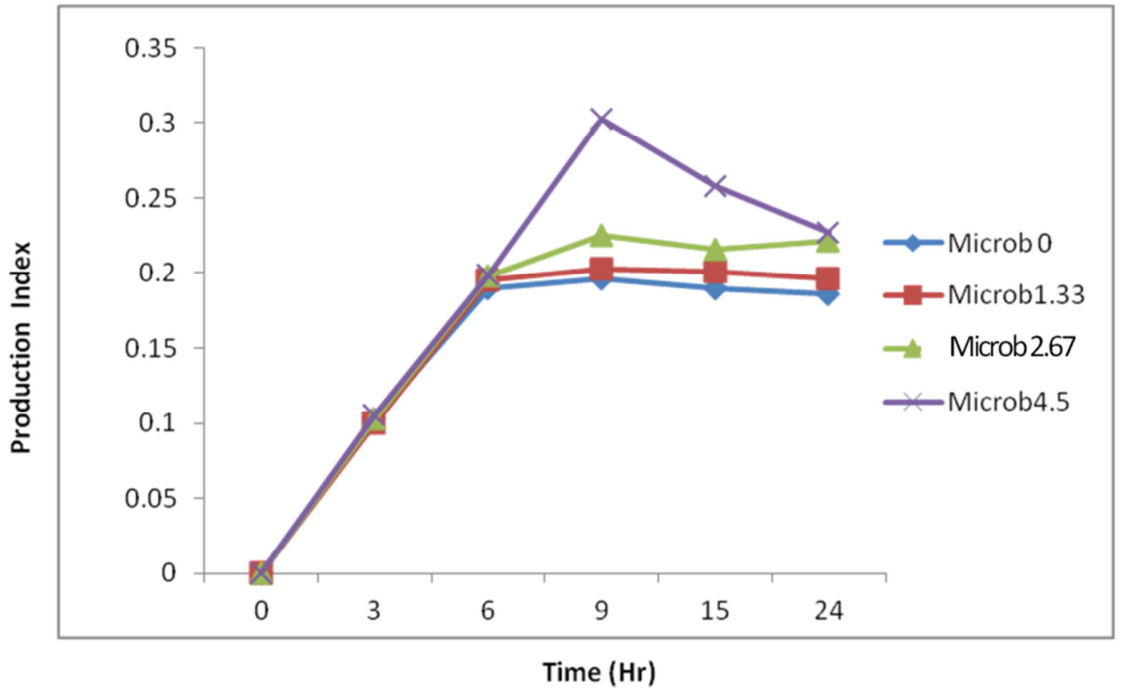

Figure 7. Variation of production Index (PI) with time and S cerevisiae for biodigestion at pH of 4. 
Table 5. Variation of Production Index with $\mathrm{pH}$ at Various Dosage of saccharomyces cerevisiae and biodigestion time of $9 \mathrm{hr}$.

Production Index at various Microbe Dosage

\begin{tabular}{lllll}
\hline $\mathbf{p H}$ & $\mathbf{0 g} / \mathbf{k g}$ & $\mathbf{1 . 3 3 g} / \mathbf{k g}$ & $\mathbf{2 . 6 7 g} / \mathbf{k g}$ & $\mathbf{4 . 5 g} / \mathbf{k g}$ \\
\hline 3.5 & 0.106 & 0.216 & 0.218 & 0.219 \\
4 & 0.196 & 0.283 & 0.295 & 0.303 \\
4.5 & 0.192 & 0.270 & 0.281 & 0.286 \\
5 & 0.188 & 0.229 & 0.232 & 0.259 \\
7 & 0.103 & 0.121 & 0.136 & 0.157 \\
\hline
\end{tabular}

The work of other scholars reported that the optimal $\mathrm{pH}$ range for yeast growth can vary from $\mathrm{pH}$ 4-6 depending on temperature, presence of oxygen and the strain of yeast [22]. Since the organisms native to the 'cow dung' is also favored within the range $4.0-5.0$ it is expected that the optimal $\mathrm{pH}$, using a combination of native microbial flora and the saccharomyces cerevisieawill be in the same range as observed in this work $(4.0-4.5)$. Therefore the result obtained in this work is in agreement with literature.

\section{Conclusion/Recommendation}

The results obtained in this work confirmed that the fertilizer value of cow dung can be enhanced by appropriate selection of bioconversion process conditions. It can also be said that the biodigestion $\mathrm{pH}$ and the dosage of saccharomyces cervisiaeaffected the production index of the biodigestion process. From these results $\mathrm{pH}$ range of 4.0 - 4.5 and precisely $\mathrm{pH} 4$, addition of $4.5 \mathrm{gm}$ of saccharomyces cerevisiea per $\mathrm{kg}$ of cow dung and bioconversion time of $9 \mathrm{hrs}$ are recommended. The use of this biodigestion process condition results in the increase in the NPK rating of cow dung from 1.8:0.18:0.84 to 2.9:0.2:1.51.

The use of this form of fertilizer should be promoted at all levels, not only for its use to improve soil fertility and hence crop yield but also to protect and improve soil structure, prevention of erosion and to protect our environment against avoidable pollutions.

This work further recommend that process of trapping of the large amount of biorganic gas evolved from this biodigestion should be developed. This gas if properly harnessed will be an economic boost to the entire process since it gives gas rich in methane.

\section{References}

[1] Abukaka, B. S. U. I and Ismail N.(2012), Anaerobic digestion of Cow dung forbiogas Production, ARPN Journal of Engineering and Applied Sciences7(2). 169-172.

[2] Adeniran, A. K, Ahaneku, I. E, Itodo, I. N and Rohjy, H. A (2014). Relativeeffectiveness of biogas production using Poultry waste and cow dung; AgricEng Int. CIGR Journal, 16(1), 126-132

[3] Andriess, J. P and Schellaas, R. M. (1987). A Monitoring study of nutrients cycles insoils used for shifting cultivation under various climatic conditions intropical Asia. Agriculture, Ecosystems and Environment 19, 285-332.

[4] Anikulapo J and Koleade O. (1995) "Strategies on house Hold waste Management”; Goethe inst. Lagos (Pp 10 93).

[5] Coomer J. C (1981) “Quest for sustainable society" pergamon press Inc. NY.

[6] Auer, A, Nathan H. VandeBurgt, Abram F., Gerald B, Owen Feuton, Markey B. K, Nelan Stephen, Karl R., Declan B, Theo De Waal, Stephen V. G, Vincent O. Flaherty Paul Whyte, AnnettaZinth (2016). Agricultural Anaerobicdigestion power plant in Ireland and Germany: Policy and Practice. Journalof Science of Food Agriculture 97(3): 719-723.

[7] Balogh E. (1978) "Review of alternative technologies of the future fuels from Biomas" Pro of Nigeria Institute of Science and Technology. 2, $106-115$.

[8] Conklin, H. C. (1961), The Study of shifting cultivation. CurrentAnthropology 2, 22-31

[9] FAO (1974), Shifting cultivation and soil conservation in Africa, Rome, FAO, SoilBulleting No. 24, Rome FAO.

[10] FAO (1979) “Agric Residues: Quantitative survey" Buttetin, Food and Agricorganization Re- United Nations- FAO.

[11] FAO (1984), Change in Shifting cultivation in Africa, FAO Forestry Paper No. 50, Rome, FAO.

[12] George, M. (2008). Rise of the anaerobic digestion. Renewable Energy Focus 9(6) 28-30.

[13] Girija D, Deepa K, Xavier F, Antony I., and P. R. Shidhi P. R, (2013). AMetagenomic approach, Indian Journal of Biotechnology Vol. 12, 372-378.

[14] Inlow D, McRae J, Ben-Basset A, (1998), Fermentation of corn starch to ethanol with genetically engineered yeast. Biotechnology and Bioengineering 32(2), 227-234.

[15] Jha A. k, Barri, Q, Zhang L, Zhao B. (2012). Dry anaerobic digestion of cow dungfor Methane production: Effect of Mixing, Pak J Boil Sci, 15(23) 1111-1118.

[16] Kim H, Im Y, Ko H, Chin J, Il-Chul Kim, I, Lee H. B, andBai S (2011). RawStarch fermentation to ethanol byan industrial distiller's yeast strain ofsaccharomyces cerevisiaeexpressing qlucoamylase and $\alpha$-amlylase genes. Biotechnology letters 33(8)1643-1648.

[17] Klinkner, B. A (2014). Anaerobic digestion as a renewable energy source andwaste management Technology. What must be done for this technology torealize success in United States? UMass Law Review 9, 79.

[18] Landstrom F. O and Mehring A. L. (1939), Complete Composition of CommercialUsed Fertilizer. Industrial and Engineering Chemistry 31(3), 354-361.

[19] Matu, S. U. (2017) Utilization of agro-wastes to produce biofertilizer, springer international publishing. Ink. Springer.com/./s50095-014-0147-8

[20] Mojovic, L., Nkikolic, S., Rakun, M. and Vikasinovic, M. (2006), Production ofbioethanol from Corn meal hydrolyzates. Fuel 85 (12-13), 1750-1755. 
[21] Mountney, G. J and Gould, W. A (1988), Oractucak Food Microbiology andTechnology, A. V. I Books, Van Nostrand Reinhold Company New York, USA.

[22] Narendranath N. V and Power R. (2005), Applied EnvironmentalMicrobiology Relationship between $\mathrm{pH}$ and Medium dissolved solids interms of growth and metabolism of lactobacilli and SaccharomycesSerevisiae during ethanol production. Applied EnvironmentalMicrobiology 71(5), 22392243.

[23] Onianwa P. C (1997) "Nature of Solid wastes and The Impact of Dumping on the Environment" Presentation at a National Workshop on Rural and urban Waste Management, University of Lagos, Nigeria $5-12$.

[24] Onwudike, S. U, (2010), Effectiveness of Cow dung and mineral fertilizer on soilproperties, Nutrient uptake and yield of sweet potato (ipomeabatatas)inSouth Eastern Nigeria, Asian Journal of Agricultural Research 4(3) 148-154

[25] Ozo, O. C, Agah M. V, Ogbu K. I, Nnachi, A. U, Udu-Ibiam O. E, Agwu, M. M (2004). Biogas Production using cow dung from Abakaliki AbattoirinSouth-Eastern Nigeria International Journal of Science and Technology, Research, 3(10), 237-239.

[26] Parfitt, R. (1976), Shifting cultivation:How it effects the soil environment. Harvest 3(2), 63-67.
[27] Salam B. S., Biswas, S., Rabbi M. S. (2012), Biogas from $\mid$ mesophilic AnaerobicDigestion of Cow dung using silica Gel as Catalyst, Procedia Engineering, 105, 652 - 657.

[28] Shigechi H, Koh J, Fujita Y, Matsumoto T, Bito Y, Ueda M, Satoh E, Fukuda H, KondoA (2004), Directproduction of ethanol from raw corn starch viafermentation by use of anovelsurface-engineering yeast straincodisplayingglucoamylase and $\alpha$-amylase. Applied and Environmental Microbiology70(8), 5037-5040.

[29] Shigechi H, Fujita Y, Koh J, Ueda M, Fukuda H, and Kondo A (2004a), Energy-saving direct ethanol production from lowtemparature-cooked corn starchusing a cell-surface engineered yeast strain co-displaying glucoamylase and $\alpha$ amylase. Biochemical Engineering Journal 18(2)149-153.

[30] Tilley, N. (2005), Cow dung Fertilizer: Learn the benefits of Cow ManureCompost www.gardeningknowhow.com. 2005

[31] Ukpai, P. A, and Nnabuchi, M. N (2012), Comparative study of biogas productionfrom cow dung, cowpea and cassava peeling using 45liters biogas digester, Advances in Applied Sciences Research 3(3) 1864-1869. 